\title{
Kebutuhan dan Pengelolaan Harta Dalam Maqashid Syariah
}

\author{
Muhammad Irwan* \\ Fakultas Ekonomi Dan Bisnis Universitas Mataram \\ *Corresponding email: dae.wan65@yahoo.com
}

\section{Info Artikel}

\section{Kata Kunci:}

Kebutuhan, Pengelolaan, Harta, Maslahah, Maqashid, syariah

\section{ABSTRAK}

Kajian ini bertujuan untuk mendeskripsikan tentang kebutuhan dan pengelolaan harta dalam Maqashid syariah. Harta merupakan salah satu kebutuhan pokok bagi manusia, karena akan menentukan kualitas kehidupannya baik masa sekarang maupun masa mendatang. Harta yang dimiliki oleh manusia harus memberi kemanfaatan (maslahah) baik bagi dirinya maupun bagi orang lain dan menghindari terjadinya kerusakan (mufsadat) yang dapat merugikan manusia itu sendiri. Maslahah merupakan tujuan syariah (maqashid syariah) dan menjadi inti utama dari syariah itu sendiri dan bersifat umum dan universal. Pengelolaan harta bagi manusia dimaksudkan untuk menggunakan harta dan membelanjakan sesuai dengan perencanaan. Pengelolaan harta dilakukan dengan mendistribusikan dan tidak menimbunnya karena berdampak pada terganggunya aktivitas ekonomi. Distribusi harta dan tidak menimbun dapat menghindarkan manusia dari sikap pelit, kikir, sombong dan individualis. Pengelolaan harta terdapat terdapat 5 langkah yang dilakukan yaitu Wealth creation/Accumulation atau penciptaan harta; (2) Wealth Consumption atau konsumsi harta; (3) Wealth purification atau penyucian harta; (4) Wealth Distribution atau distribusi harta; dan (5) Wealth protection atau perlindungan harta.

\section{PENDAHULUAN}

Aktivitas kehidupan manusia dengan bekerja sehari-hari tujuan akhirnya bermuara kepada pemenuhan berbagai kebutuhan salah satunya adalah harta. Tidaklah mengherankan, pembahasan dan pembicaraan tentang harta menjadi bagian tak terpisahkan dalam perjalanan kehidupan manusia. Demikian halnya dalam dunia keilmuan, permasalahan harta menjadi isu pokok dalam ilmu ekonomi. Pembahasan harta menjadi sangat sentral, lantaran ia seringkali menjadi konflik dalam hubungan antar manusia (Al-Faizin dan Zain, 2018). Sistem-sistem ekonomi baik sistem ekonomii konvensional (kapitalis dan sososial) maupun ekonomi Islam menempatkan harta menjadi 


\section{Elastisitas - Jurnal Ekonomi Pembangunan \\ Vol. 3 No. 2, September 2021}

sebuah kajian utama dengan sudut pandang yang berbeda.

Ikhtiar manusia untuk memenuhi kebutuhan hidup semakin kompleks sehingga diperlukan adanya pengorbanan dan persaingan yang keras untuk memperoleh harta. Kebutuhan manusia berbeda antara satu dengan lainnya dan mengalami peningkatan serta bervariatif. Kebutuhan manusia dalam paradigma ekonomi konvensional dikatakan tidak terbatas sementara sumberdaya alam sifatnya terbatas yang menyebabkan terjadinya kelangkaan atau kekurangan sumberdaya (Sukirno, 2015). Kelangkaan akan barang dan jasa timbul bila kebutuhan (keinginan) seseorang atau masyarakat ternyata lebih besar dari tersedianya barang dan jasa tersebut. Jadi, kelangkaan itu akan muncul apabila tidak cukup barang dan jasa untuk memenuhi kebutuhan dan keinginan tersebut (Nasution, dkk, 2006).

Ekonomi Islam yang menerapkan nilai-nilai Ilahiah bertujuan untuk menghantarkan manusia memenuhi kebutuhan materinya di dunia sehingga tercapai kesejahteraan yang akan membawa kepada kebahagiaan di dunia dan di akhirat atau falah (P3EI, 2008). Istilah falah merujuk kepada kebahagian spritual moral, dan sosial ekonomi di dunia dan kesuksesan di akhirat (Chaudry, 2012). Falah adalah kemuliaan dan kemenangan dalam hidup. Istilah falah menurut Islam diambil dari kata-kata AlQur'an yang sering dimaknai sebagai keberuntungan jangka panjang dunia dan akhirat, sehingga tidak hanya memandang aspek material namun justru lebih ditekankan pada aspek spritual (Aravik dan Fakhry Zamzam, 2020).

Harta dalam ekonomi islam menjadi fokus pembahasan karena berkenaan dengan kemaslahatan hidup manusia baik individu maupun bersama (sosial). Al-Qur'an, Alhadis maupun ijtihad para ulama sebagai sumber hukum ekonomi Islam telah memberikan batasan yang jelas tentang harta. Manusia yang berkaitan langsung dengan harta telah diberi petunjuk tentang cara memperoleh, mengelola harta yang berada pada dirinya. Manusia sebagai khalifah Allah wajib untuk melakukan ibadah termasuk bekerja untuk mencari harta. Penekanan
Islam terhadap masalah harta, karena berdampak pada kehidupan manusia bahkan dapat memempatkan manusia menjadi makhluk yang mulia maupun yang terhina.

Harta merupakan salah satu kebutuhan esensial atau dasar bagi manusia, karena akan menentukan kualitas kehidupannya baik masa sekarang maupun masa mendatang. Menurut Aprianto (2017), harta dalam pandangan Islam pada hakekatnya merupakan milik Allah, dimana Allah telah menyerahkan kepada manusia untuk menguasai harta tersebut sehingga orang tersebut sah memiliki hartanya. Untuk itu dalam pandangan Islam harta memiliki kedudukan yang penting. Harta yang dimiliki oleh manusia harus memberi kemanfaatan (maslahah) baik bagi dirinya maupun bagi orang lain dan menghindari terjadinya kerusakan (mufsadat) yang dapat merugikan manusia itu sendiri. Maslahah merupakan tujuan syariah (maqashid syariah) dan menjadi inti utama dari syariah itu sendiri dan bersifat umum dan universal.

Maqasyid syariah bertujuan untuk menegakkan kemaslahatan manusia sebagai makhluk sosial, yang mana ia harus bertanggung jawab atas dirinya sendiri dan -pada akhirnya nanti--pada Allah (Fauzia dan Riyadi, 2014). Harta yang menjadi kebutuhan pokok bagi manusia dalam kehidupannya harus dapat dijaga dan dipelihara keberadaannya. Di samping itu, terjaminnya harta yang berada pada setiap manusia bergantung cara mengelolanya yang tentunya harus sesuai dengan kaidah hukum syariah. Semuanya yang telah digariskan oleh Islam berkenaan dengan harta bagi manusia tiada lain untuk menghantarkan manusia berada dalam kebahagiaan hidup baik di dunia maupun di akhirat. Hal itu dapat terwujud bila manusia mampu menjalankan dan menerapkan tujuan syariah (maqashid syariah) dalam menjalani proses kehidupannya di dunia. Tulisan ini bertujuan untuk mendeskripsikan kebutuhan dan pengelolaan harta dalam Maqashid Syariah. Uraian ini akan memberikan sumbangsih pemahaman terhadap pemecahan terhadap cara dan ikhitar manusia untuk memenuhi berbagai kebutuhan hidup salah satunya adalah harta. 


\section{Elastisitas - Jurnal Ekonomi Pembangunan \\ Vol. 3 No. 2, September 2021}

\section{TINJAUAN PUSTAKA}

\section{Pengertian Harta}

Harta memiliki makna yang beragam tergantung dari sudut pandang orang yang mendefinisikannya. Harta bagi sebahagian orang dapat disamakan dengan kekayaan berupa benda yang dimiliki baik yang bergerak maupun yang tidak bergerak yang menjadi kekuasaan dan miliknya. Pengertian harta mengacu pada beberapa penulis seperti (1) Ath-Tharsyah (2004) memandang harta adalah apa saja yang dimiliki dan digunakan oleh seseorang berupa : uang, rumah, perabot, mobil, tanah, kebun, ternak dan lainlain. Harta adalah hiasan hidup di dunia yang disukai setiap orang dan berusaha untuk memilikinya dengan berbagai cara. Pandangan Islam mengenai harta, bahwa harta itu merupakan milik Allah SWT. Harta yang merupakan hak milik-Nya itu, diberikan kepada orang-orang yang dikehendaki-Nya untuk dibelanjakan pada jalan-Nya. (2) Menurut Wahbah Zuhaili (Djuwaini, 2010), secara linguistik, al-mal didefinisikan sebagai segala sesuatu yang dapat mendatangkan ketenangan, dan bisa dimiliki oleh manusia dengan sebuah upaya ( $\left.f i^{\prime \prime} i l\right)$ baik sesuatu itu berupa zat (materi) ataupun berupa manfaat. (3) Harta adalah setiap mata uang yang boleh dimanfaatkan atau segal sesuatu yang boleh dimanfaatkan kecuali hal-hal yang dikecualikan oleh pembuat syariat (AlMusyaiqi, 2012). (4) secara terminologis harta adalah sesuatu yang diinginkan manusia berdasarkan tabiatnya, baik manusia itu akan memberikannya atau menyimpannya (Mardani,2012).

Menurut Ash-Shiddieqy (2009), pengertian harta dapat dilihat dari beberapa katagori yaitu (1) harta (mal) adalah nama bagi yang selain manusia, yang ditetapkan untuk kemaslahatan manusia, dapat dipelihara pada satu tempat, dapat dilakukan tasharruf dengan ikhtiar; (2) benda yang dijadikan harta itu, dapat dijadikan harta oleh umum manusia atau oleh sebagian mereka; (3) sesuatu yang tidak dipandang harta, tidak sah untuk menjualnya; (4) sesuatu yang dimubahkan walaupun tidak dipandang harta seperti sebiji berar, sebiji beras tidak dipandang harta walaupun dia boleh kita miliki; (5) harta itu wajib mempunyai wujud.
Karenanya manfaat tidak masuk ke dalam bagian harta, karena tidak mempunyai wujud; (6) benda yang dapat dijadikan harta, dapat disimpan untuk waktu tertentu, atau untuk waktu yang lama dan dipergunakan diwaktu ia dibutuhkan.

Berdasarkan beberapa definisi harta di atas dapat diketahui harta merupakan segala sesuatu yang diinginkan oleh manusia dan dibutuhkannya, kemudian dimanfaatkan untuk memenuhi berbagai kebutuhan hidupnya. Harta dapat dikuasai manusia tidak hanya berupa benda bergerak maupun tidak bergerak, namun tidak dapat dimiliki secara mutlak karena hanya berupa titipan yang dimanfaatkan sebaik-baiknya sesuai dengan petunjuk Al-Qur'an dan Al-hadis.

\section{Pengertian Kebutuhan dan Jenisnya}

Kebutuhan berasal dari kata butuh yang berarti barang apa yang diperlukan; hajat, kepentingan (Poerwadarminta, 1984). Menurut Al-Ghazaly, kebutuhan (hajat) adalah keinginan manusia untuk mendapatkan sesuatu yang diperlukan dalam rangka mempertahankan kelangsungan hidupnya dan menjalankan fungsinya (Nasution, dkk, 2006). Kebutuhan (hajat) adalah sesuatu yang dibutuhkan manusia agar dapat terpenuhi (Chalil, 2009). Manusia dalam menjalani kehidupannya di dunia membutuhkan berbagai unsur kehidupan baik yang bersifat materi maupun non materi. Kebutuhan manusia untuk memenuhi kehidupannya sangat banyak sehingga harus diadakakan pilihan dan skala prioritas. Kebutuhan berkaitan dengan sesuatu yang harus dipenuhi agar suatu barang bergungsi dengan sempurna (P3EI, 2008).

Kebutuhan manusia telah dipilah oleh beberapa ahli seperti Abraham H. Maslow (1954) yang telah menyusun kebutuhan manusia menjadi 5 tingkatan yaitu (1) Kebutuhan fisiologis atau dasar; (2) Kebutuhan akan rasa aman; (3) Kebutuhan untuk dicintai dan disayangi; (4) Kebutuhan untuk dihargai; dan (5) Kebutuhan untuk aktualisasi diri. Menurut Boere, yang dikutip Yahya (2020), Maslow menyebutkan bahwa empat kebutuhan mulai dari kebutuhan fisiologis sampai dengan kebutuhan harga diri dengan sebutan homeostatis, kemudian berhenti dengan sendirinya. 


\section{Elastisitas - Jurnal Ekonomi Pembangunan \\ Vol. 3 No. 2, September 2021}

Rosyidi (2000) menyatakan bahwa kebutuhan manusia bertingkat-tingkat yaitu tingkat pertama adalah primary needs atau kebutuhan primer terdiri dari sandang, (pakaian), pangan (makanan dan minuman), dan papan (tempat tinggal). Kalau kebutuhan primer ini sudah tercapai maka muncullah di dalam pikiran manusia untuk memenuhi kebutuhan tingkat kedua yaitu secondary needs, yang antara lain berisi kebutuhan akan sepatu, sepeda, pendidikan dan sebagainya. Demikianlah adanya sehingga terdapatlah kebutuhan tingkat ketiga adalah tertiary needs, kebutuhan tingkat keempat (quartiary needs) dan seterusnya. Lebih lanjut dijelaskannya bahwa manusia juga memiliki kebutuhan badaniah atau kebutuhan fisik maupun kebutuhan psikis atau kebutuhan kejiwaan. Sementara Sukirno (2015) menguraikan kebutuhan dalam lingkup yang luas yaitu kebutuhan masyarakat adalah keinginan masyarakat untuk memperoleh barang dan jasa. Barang yang dibutuhkan manusia terutama terdiri dari benda yang dapat dilihat dan diraba secara fisik seperti pakaian, makanan dan minuman., Di samping itu ada juga barang yang tidak dapat diraba dan dilihat seperti udara. Jasa yang dibutuhkan manusia merupakan layanan seseorang atau suatu barang yang akan memenuhi kebutuhan masyarakat.

Ilmuwan Islam dan ulama-ulama telah terlebih dahulu menguraikan berbagai jenis kebutuhan manusia dalam menjalani proses kehidupannya di dunia. Berdasarkan firman Allah dan hadis-hadis nabi ilmuwan-ilmuwan islam telah mampu menghasilkan pemikiran, teori-teori yang berkenaan dengan kehidupan manusia termasuk dalam aktivitas ekonomi. Salah satu aktivitas ekonomi yang dibahas oleh para ilmuwan dan ulama, di antaranya adalah berkenaan dengan pemenuhan kebutuhan hidup manusia di dunia maupun di akhirat. Di antara ilmuwan Islam sekaligus dan ulama yang telah mengklasifikasi berbagai jenis kebutuhan manusia adalah Abu Ishaq al Syathibi disebut pula dengan Iman asy-Syathibi.

Asy-syathibi telah mengemukakan teori tentang the basic need yang terangkum dalam konsep maqashdi al-syariah. Syatibi merangkum kebutuhan manusia menjadi dharuriyat, hajiyat dan tahsiniyat. Selanjutnya, dharuriyat terbagi menjadi lima poin yaitu al -khamsah yaitu : 1) penjagaan terhadap agama (hifz al-din); 2) penjagaan terhadap jiwa (hifz al-nafs); 3) penjagaan terhadap akal (hifz al-aql); 4) penjagaan terhadap keturunan (hifz al-nasl); dan (5) penjagaan terhadap harta ( hifzl al-mal) (Fauzia dan Riyadi, 2014). Kelima kebutuhan dharuriyat tersebut adalah yang mutlak harus ada pada manusia. Karenanya Allah menyuruh untuk melakukan segala upaya bagi keberadaan dan kesempurnaanya. Sebaliknya, Allah melarang melakukan perbuatan yang dapat menghilangkan atau mengurangi salah satu dari lima dharuriyat yang lima itu (Susilawati, 2015).

Pengertian dari jenis-jenis kebutuhan tersebut adalah 1) Daruriyyat merupakan kebutuhan/tujuan yang harus ada dan mendasar bagi penciptaan kesejahteraan di dunia dan akhirat, yaitu mencakup terpeliharanya lima elemen dasar kehidupan yakni keyakinan atau agama, jiwa, akal/intelektual, keturunan dan keluarga serta harta benda. Jika kebutuhan/tujuan dharuriyat diabaikan, maka tidak akan ada kedamaian, yang timbul adalah kerusakan (fasad) di dunia dan kerugian yang nyata di akhirat; 2) Hajiyyat, syariah bertujuan memudahkan kehidupan dan menghilangkan kesempitan. Hukum syara dalam katagori ini tidak dimaksudkan untuk memelihara lima hal pokok tadi melainkan menghilangkan kesempitan dan berhati-hati terhadap lima hal pokok tersebut; 3) Tahsiniyyat. Syariah menghendaki kehidupan yang indah dan nyaman di dalamnya. Terdapat beberapa provisi dalam syariah yang dimaksudkan untuk mencapai pemanfaatan yang lebih baik, keindahan simplifikasidari dhariuryat dan hajjiyat. Misalnya dibolehkan memakai baju yang nyaman dan indah. berarti penyempurna. Tingkat kebutuhan ini berupa kebutuhan pelengkap (Nasution, dkk, 2006).

Berdasarkan tingkat kebutuhan ini, kebutuhan dharuriyah merupakan kebutuhan pokok yang harus dipenuhi oleh manusia untuk mencapai kemaslahatan kehidupan berupa kesejahteraan di dunia dan diakhirat. Kebutuhan hajjiyat tidak termasuk kebutuhan pokok meskipun tidak terpenuhi tidak akan mengamcam kehidupan manusia 


\section{Elastisitas - Jurnal Ekonomi Pembangunan \\ Vol. 3 No. 2, September 2021}

namun akan membawa kesulitan dalam kehidupannya. Kebutuhan Tahisniyat merupakan kebutuhan penunjang dan jika tidak terpenuhi tidak akan membawa kehidupan manusia menjadi sulit sebagaimana kebutuhan hajjiyat, namun tidak sesuai dengan fitrahnya sebagai manusia. Menurut Abdul Wahab Kallaf, jika tiga peringkat kebutuhan tersebut masing-masing dharuriyat, hajiyat dan tahsiniyat telah dipenuhi secara sempurna maka kemaslahatan manusia yang merupakan tujuan hukum syariat dapat terealisasi (Cholisni dan Kiki Damayanti, 2016).

\section{Pengertian Pengelolaan}

Pengelolaan berasal dari kata kelola, dalam Kamus Besar Bahasa Indonesia berarti menyelenggarakan (organisasi, pemerintahan, perusahaan, dsb), mengurus (proyek, dsb). Pengelolaan adalah proses yang memberikan pengawasan pada semua hal yang terlibat dalam pelaksanaan kebijaksanaan dan pencapaian tujuan; proses melakukan kegiatan tertentu dengan menggerakkan tenaga orang lain (Tim Prima Pena, tt). Pengelolaan dapat dimaknai dengan manajemen, sebagaimana yang ditulis oleh Anwar (2020) bahwa manajemen berasal dari bahasa Inggris management dengan kata kerja to manage yang berarti mengurusi. Jusmaliani (2011) menggunakan terminologi Pengelolaan Sumber Daya Insani sebagai pengganti terminologi Manajemen Sumber Daya Manusia.

Menurut Sukarna (Fakhrudin, 2008), kata manage mempunyai beberapa arti yaitu (1) to direct and control (membimbing dan mengawas); (2) to treat with care (memperlakukan dengan seksama); (3) to carry business or affairs (mengurus perniagaan atau urusan-urusan/persoalanpersoalan); (4) to achieve one's purpose (mencapai tujuan tertentu). Mengacu dari pengertian ini, salah satu arti dari manage sebagai asal kata management adalah mengurus yang dimaknai sama dengan pengelolaan. Pengelolaan dapat pula dikaitkan dengan makna kata ekonomi yang berasal dari kata oikos dan nomos. Kata-kata ini oleh orang-orang barat menterjemahkannya dengan management of household or estate yang artinya tata laksana rumah tangga atau pemilikan (Rosyidi, 2000). Dalam hal ini management diartikan dengan tatalaksana atau mengurus atau mengelola rumah tangga baik berkenaan dengan hal-hal atau kepemilikan yang bersifat material maupun non material.

Sinn (2008) mengatakan, manajemen bila dilihat dalam tataran ilmu, dipandang sebagai kumpulan pengetahuan yang dikumpulkan, disestimisasi dan diterima berkenaan dengan ketentuan-ketentuan universal mengenai manajemen. Dalam tataran seni (praktek), managemen diartikan dengan kekuatan pribadi yang kreatif ditaambah dengan skill dalam pelaksanaan. Manajemen merupakan seni karena ia merupakan organisator dan pemanfaat bakat manusia (the art of getting think done though people). Arti manajemen menurut James A.F. Stoiner adalah proses perencanaan, pengorganisasian, pengarahan dan pengawasan usaha-usaha para anggota organisasi dan penggunaan sumber dayasumber daya organisasi lainnya agar mencapai tujuan organisasi yang telah ditetapkan (Handoko, 2013).

Pengelolaan atau manajemen dalam Islam berbeda dengan manajemen konvensional dilihat dari sumber hukum pelaksanaannya. Manajemen Islam bersumber dari nash-nash Al-Qur'an dan petunjuk Sunah. Ia juga berasaskan pada nilai-nilai kemanusiaan yang berkembang dalam masyarakat pada waktu tersebut. Manajemen Islam lebih memfokuskan pada segala variabel yang berpengaruh (influence) terhadap aktivitas manajemen dalam dan luar organisasi (perusahaan, negara), dan hubungan perilaku individu terhadap faktor-faktor sosial yang berpengaruh. Teori Islam memberikan injeksi moral dalam manajemen, yakni mengatur bagaimana seharusnya individu berperilaku. Tidak ada manajemen Islam kecuali ada nilai atau etika yang melingkupinya, sebagaimana tidak mungkin membangun masyarakat muslim tanpa didasari dengan akhlak (Sinn, 2008).

Kehidupan manusia selalu ingin memenuhi dan memiliki kebutuhan hidup salah satunya adalah harta. Harta sebagi kebutuhan primer menjadi kewajiban manusia untuk memperoleh dan 
mendapatkannya. Islam secara tegas telah memberikan rambu-rambu kepada manusia cara-cara memperoleh harta sebagai kebutuhan, memelihara dan menjaga sekaligus mengelolanya. Ketentuan Islam ini semata-mata bertujuan agar manusia tidak terlena dan tergoda akan harta sehingga melupakan pemilik hakiki harta tersebut yaitu Allah SWT, dan manusia hanyalah penerima amanah untuk mengelola harta tersebut dengan sebaik-baiknya. Tujuannya adalah agar manusia dapat memperoleh kemaslahatan serta mencapai kesejahteraan hakiki yaitu di dunia dan akhirat (falah). Pencapaia al-falah merupakan tujuan dari syariah Islam atau Maqashid Syariah.

Pengelolaan harta kekayaan secara Islami dikenal juga sebagai perencanaan keuangan keluarga secara Syariah (Islamic Financial Planning) merupakan industri keuangan yang berfungsi untuk mengelola kekayaan masyarakat muslim untuk dapat diinvestasikan maupun dikelola dengaan cara-cara yang halal dan thoyyib. Pengelolaan harta kekayaan islamu meliputi aspek perolehan atau penciptaan harta, peningkatan harta kekayaan, perlindungan harta, pendistribusian kekayaan dan pemurnian kekayaan. Syariat Islam mengajarkan bahwa harta kekayaan dapat digunakan untuk banyak tujuan namun tidak diperbolehkan untuk dibelanjakan pada halhal yang dilarang syara' (Choirunnisak, 2017).

\section{Pengertian Maqashid Syariah}

Secara etimologi, maqashid syariah terdiri dari dua kata, yaitu maqashid yang merupakan bentuk jamak dari maqshud yang berarti tujuan. Adapun syariah artinya jalan menuju air, atau bisa dikatakan dengan jalan menuju ke arah sumber kehidupan (Fauzia, 2014). Menurut Efendi yang dikutip oleh Cholisni dan Kiki Damayanti (2016) Maqasyid syariah merupakan tujuan Allah dan RasulNya dalam merumuskan hukumhukum Islam. Tujuan itu dapat ditelusuri dalam ayat-ayat Al-Qur'an dan sunnah Rasulullah sebagai alasan logis bagi rumusan suatu hukum yang berorientasi kepada kemaslahatan manusia.

Terdapat beberapa definisi maqashid syariah yang diungkapkan oleh para ulama terdahulu yaitu ( Fauzia dan Riyadi, 2014) :

1. Al-Ghazali. Secara terminologi maqashid syariah adalan penjagaan terhadap maksud dan tujuan syariah adalah upaya mendasar untuk bertahan hidup, menahan faktor - faktor kerusakan dan mendorong terjadinya kesejahteraan.

2. Al-Syatibi. Maqashid terbagi menjadi dua yaitu pertama ; berkaitan dengn maksud Tuhan selaku pembuat syariah dan kedua ; berkaitan dengan maksud mukallaf .

3. Al-Farisi. Maqasyid al -syariah adalah tujuan pokok syariah dab rahasia dari setiap hukum yang ditetapkan Tuhan.

4. Ahmad Al-Rasyuni, Maqashid syariah merupakan tujuan - tujuan yang telah ditetapkan oleh syariah untuk dicapai demi kemaslahatan manusia

5. Abdul Wahab Kallaf, Tujuan utama ketika Allah menentukan hukum-hukum-Nya adalah untuk mewujudkan kemaslahatan dan kesejahteraan hidup manusia dengan terpenuhinya kebutuhan yang dharuriyah, hajiyah dan tahsiniyah.

6. Wahab Al-Zuhaili mengatakan bahwa maqashid syariah adalah nilai-nilai dan syara' yang tersirat dalam segenap atau bagian terbesar dari hukum-hukum-Nya. Nilai -nilai dan sasaran -sasaran itu dipandang sebagai tujuan dan rahasia syariah, yang ditetapkan oleh al-syar'i dalam setiap ketentuan hukum.

7. Yusuf Al-Qardhawi mendefinisikan maqashid syariah sebagai tujuan yang menjadi target teks dan hukum - hukum partikular untuk direalisasikan dalam kehidupan manusia, baik berupa perintah, larangan dan mubah, untuk individu, keluarga, jemaah dan umat, atau juga disebut dengan hikmah - hikmah yang menjadi tujuan ditetapkannya hukum, baik yang diharuskan ataupun tidak.

Maqashid syariah bertujuan untuk mengetahui tujuan-tujuan yang hendak dicapai oleh perumusnya dalam mensyariatkan hukum. Tujuan ini merupakan salah satu faktor penting dalam menetapkan hukum Islam yang dihasilkan melalui ijtihad (Mizani, 2015). Maqasyid syaria atau tujuan syariah memiliki kemaslahatan inti/pokok yang disepakati dalam lima hal, yaitu (Jauhar, 2009; Hadi; 2012) : 
1. Menjaga agama (hifdz ad-Din); sebagai jalan alasan diwajibkannya berdakwah, bermuamalah secara Islami; dan berjihad jika ditujukan untuk para musuh atau tujuan senada.

2. Menjaga jiwa (hifdz An-Nafs); sebagai jalan alasan diwajibkannya hukum qishash di antaranya dengan menjaga kemuliaan dan kebebasannya.

3. Menjaga akal (hifdz Al-Aq'al); sebagai jalan alasan diwajibkannya menuntut ilmu sepanjang hayat; diharamkannya mengkonsumsi benda yang memabukkan dan narkotika dan sejenisnya.

4. Menjaga keturunan (hifdz An-Nasl); sebagai jalan alasan diwajibkannya mempelajari kualitas keturunan, dan diharamkannya berzina dan menuduh orang lain berzina.

5. Menjaga harta (hifdz Al-Mal); sebagai jalan alasan diwajibkannya pengelola dan mengembangkan harta atau kekayaan, sebab dengan kekayaan yang kita miliki membuat kita mampu menjaga empat tujuan yang di atasnya. Serta diharamkannya pencurian, suap, bertransaksi riba dan memakan harta orang lain secara bhatil.

Kelima hal tersebut merupakan kebutuhan dasar manusia yaitu kebutuhan mutlak yang harus dipenuhi agar manusia dapat hidup bahagia di dunia dan akhirat. Jika salah satu dari kebutuhan di atas tidak terpenuhi dengan tidak seimbang niscaya kebahagiaan kehidupan juga tidak tercapai dengan sempurna (P3EI, 2008).

\section{METODE PENETIAN}

Penelitian atau kajian ini berkaitan dengan kebutuhan dan pengelolaan harta dalam maqashid syariah. Penelitian ini hanya mendiskripsikan dan menguraikan permasalahan yang berkenaan dengan kebutuhan dan pengelolaan harta yang melakukan penelaahan terhadap berbagai literatur yang berkaitan langsung dengan permasalahan yang dikaji.

\section{PEMBAHASAN}

Manusia dalam proses kehidupannya selalu berupaya untuk memenuhi kebutuhannya baik materil maupun sprituil.
Untuk dapat memenuhi kebutuhan tersebut, manusia berupaya untuk melakukan aktivitas dengan mencari sumber-sumber kebutuhan yang sudah tersebar di permukaan bumi dengan dilandasi oleh adanya moral dan akhlaq. Islam tidak membatasi manusia untuk memenuhi kebutuhannya, tetapi dianjurkan untuk memenuhi kebutuhan-kebutuhan dengan maksimal sepanjang sesuai dengan koridor Islam. Salah satu kebutuhan dari sekian banyak kebutuhan manusia adalah kebutuhan terhadap harta. Harta atau disebut pula dengan kekayaan merupakan kebutuhan pokok yang dapat menghantarkan manusia mencapai kemaslahatan dalam hidupnya atau akan membawanya dalam kerusakan dan kehancuran.

\section{Kebutuhan/Pemeliharaan Terhadap Harta}

. Harta merupakan salah satu komponen utama yang harus dan wajib dipenuhi oleh setiap manusia dalam menjalani kehidupannya sehari-hari. Harta dalam ekonomi merupakan alat pemuas kebutuhan manusia karena tanpa adanya harta kehidupan manusia tidak akan stabil bahkan tidak dapat mempertahankan kehidupannya. Begitu pentingnya kedudukan dan fungsi harta bagi manusia, maka tidak ada satupun manusia yang tidak membutuhkannya. Allah SWT dengan sifat Kasih Sayangnya kepada umat-Nya, telah menyediakan berbagai jenis sumber daya yang dapat dimanfaatkan sebagai bekal kehidupannya. Sebahagian besar sumber daya alam tersebut masih dalam keadaan asli sehingga diperlukan campur tangan manusia untuk mengolah dan memproduksi kembali agar menjadi harta benda yang dapat memberikan manfaat (maslahah) bagi kehidupannya untuk mencapai kesejahteraan baik untuk kehidupan di dunia maupun akhirat (falah).

Kebutuhan manusia terhadap harta merupakan suatu keniscayaan, karena harta merupakan salah satu dari kebutuhan pokok yang harus diwujudkan sekaligus sebagai sarana bagi manusia untuk melangsungkan proses kehidupannya di dunia. Harta pula yang menjadi jalan bagi manusia beriman untuk berhubungan dengan penciptanya melalui rangkaian ibadah yang telah diperintahkan baik yang bersifat wajib 
maupun sunah. Kecenderungan manusia untuk mendapatkan harta merupakan sifat yang melekat di dalam diri manusia. Kebutuhan manusia terhadap harta sebagai kebutuhan dharuriyah akan terus berlangsung dan diwujudkan. Pemenuhan kebutuhan ini akan berhenti ketika aktivitas kehidupannya di dunia berakhir. Islam telah memberikan penekanan kepada manusia bahwa kuantitas harta yang dibutuhkan dan yang telah diperoleh harus memberikan kemasalahatan atau manfaat bagi perkembangan kualitas kehidupannya secara individu dan untuk kemaslahatan bersama (sosial).

Penekanan Islam kepada manusia agar harta juga memberikan kemanfaataan bagi kemaslahatan bersama mengacu pada fungsi dari harta itu sendiri, salah satunya berfungsi secara sosial. Menurut Qadir (1998), berkaitan dengan fungsinya sebagai fungsi sosial, harta tidak semata-mata dalam peranannya sebagai barang konsumtif yang dibagi-bagikan dan dibutuhkan oleh masyarakat, tetapi lebih berperan dalam fungsi ekonomi-edukatif yaitu :

a. Sirkulatif-distributif. Dalam sistem ekonomi masyarakat untuk mencegah terkonsentrasinya modal atau harta ditangan orang kaya (agniya), jangan sampai harta itu bereda di antara orang kaya saja. Harta harus disalurkan pada bidang-bidang produktif, bekerja sama dengan masyarakat golongan ekonomi lemah yang membutuhkan pekerjaan sebagai sumber penghasilan.

b. Bahwa sifat harta adalah berkembang dan nilainya berkembang. Nilai edukatif harta bertujuan untuk mendidik manusia menjauhi sifat tamak dan bakhil yang bertentangan dengan tujuan Tuhan memberikan harta kepada seseorang, sebagaimana firman Allan yang terdapat dalam surat Ali-Imran ayat 180 : “ Sekali-kali janganlah orang-orang yang bakhil dengan harta yang Allah berikan kepada mereka dari karuniaNya menyangka, bahwa kebakhilan itu baik bagi mereka. Sebenarnya kebakhilan itu adalah buruk bagi mereka. Harta yang mereka bakhilkan itu akan dikalungkan kelak di lehernya di hari kiamat. Dan kepunyaan Allah-lah segala warisan (yang ada) di langit dan di bumi. Dan Allah mengetahui apa yang kamu kerjakan.

c. Efektif, yaitu harta sebagai modal harus berperan dala berbagai lapangan produktif, yang akhirnya akan tersalur dalam berbagai lapangan usaha secara distributif yang dapat menampung dan menjalankan produktivitas dan efektivitas ekonomi dan menghindari terjadinya penimbunan harta yang sangat merugikan orang banyak dan pemilik harta itu sendiri.

Harta bagi manusia dapat memberi dampak terhadap keberlangsungan kehidupan manusia agar mampu memenuhi kebutuhan pokok lainnya maupun kebutuhan sekunder maupun tertier. Harta dapat dijadikan modal untuk dapat berusaha atau melakukan aktivitas lainnya. Harta juga dapat membedakan manusia yang tergolong berharta (kaya) maupun sedikit atau tidak memiliki harta (miskin). Kaya dan miskin oleh manusia itu sendiri dapat membedakan status sosial yang berbeda. Padahal dalam AlQur'an secara jelas yang membedakan manusia disisi Tuhannya adalah takwa. Demikian halnya hadis Rasulullah SAW yang menyatakan bahwa "Bukanlah kekayaan itu dengan banyaknya harta benda, tetapi kekayaan yang sejati adalah kaya hati" (HR. Bukhari dan Muslim). Berdasarkan firman Allah ini maka manusia tidak dibedakan berdasarkan kaya dan miskin melainkan ketakwaanya kepada Allah SWT. Demikian halnya kekayaan bukanlah dilihat dari harta yang melimpah, namun adalah kaya hati. Hati atau jiwa dalam Maqashid Syariah merupakan salah satu kebuhan pokok yang harus dijaga, dikelola dan dipelihara serta wajib dijaga dengan baik.

Manusia yang diberi unsur kehidupan salah satunya nafsu, memiliki sifat dan keinginan yang selalu bertambah dan tidak terbatas terhadap sesuatu termasuk harta. Ikhtiar manusia untuk memperoleh harta sebagai kebutuhan, memiliki karakter yang bervariatif, dilakukan dengan cara berbedabeda sesuai dengan kemampuan dan ilmu yang dimilikinya. Keinginan manusia terhadap harta semakin mengalami peningkatan dari waktu ke waktu dan jumlahnya tidak terbatas, meski kebutuhan 


\section{Elastisitas - Jurnal Ekonomi Pembangunan \\ Vol. 3 No. 2, September 2021}

terhadap harta tersebut jumlahnya terbatas. Terdapat beberapa karakter manusia berkenaan dengan kebutuhan dan sikapnya terhadap harta yaitu :

\section{Manusia yang sangat cinta terhadap} harta.

Manusia jenis ini adalah manusia yang benar-benar mencintai hartanya melebihi cintanya pada yang lain bahkan terhadap Allah SWT yang menciptakannya. Mengenai hal ini Allah SWT telah berfirman "dan kamu mencintai harta benda dengan kecintaan yang berlebihan. Manusia jenis ini mencintai hartanya diluar batas kewajaran, dan cenderung berlaku tidak rasional.

2. Suka mengumpulkan kemudian menghitung-hitungnya. Allah berfirman "Kecelakaanlah bagi setiap pengumpat lagi pencela; yang mengumpulkan harta dan menghitung-hitung;__dia mengira bahwa hartanya itu dapat mengkekalkannya; sekali-kali tidak! Sesungguhnya dia benar-benar akan dilemparkan ke dalam Huthamah".

3. Berbangga-bangga dengan hartanya. Allah berfirman "Ketahuilah, bahwa sesungguhnya kehidupan dunia ini hanyalah permainan dan suatu yang melalaikan, perhiasan dan bermegahmegah antara kamu serta berbanggabanggaan tentang banyaknya harta dan anak, seperti hujan yang tanamtanamannya mengagumkan para petani; kemudian tanaman itu menjadi kering dan kamu lihat warnanya kuning kemudian menjadi hancur. Dan di akhirat (nanti) ada azab yang keras dan ampunan dari Allah serta keridhaan-Nya. Dan kehidupan dunia ini tidak lain hanyalah kesenangan yang menipu”.(Al-Hadid, 20).

4. Sikap kikir terhadap harta. Allah berfirman "Sekali-kali janganlah orangorang yang bakhil dengan harta yang Allah berikan kepada mereka dari karuniaNya menyangka, bahwa kebakhilan itu baik bagi mereka. Sebenarnya kebakhilan itu adalah buruk bagi mereka. Harta yang mereka bakhilkan itu akan dikalungkan kelak di lehernya di hari kiamat. Dan kepunyaan Allah-lah segala warisan (yang ada) di langit dan di bumi. Dan Allah mengetahui apa yang kamu kerjakan. (Kementerian Agama RI, 2012).

Islam dengan segala keisitimewaannya telah memberi ramb-rambu dengan jelas kepada manusia tentang cara memperoleh harta, menjaga serta memeliharanya. Harta merupakan salah satu kebutuhan pokok yang tidak boleh tidak harus dipenuhi dengan cara yang telah digariskan dan ditentukan oleh Islam. Islam tidak menginginkan umatnya terbelenggu oleh harta yang cara memperolehnya tidak sesuai syariah Islam. Syariah Islam bertujuan untuk menghantarkan umatnya untuk mencapai kesejahteraan di dunia dan akhirat (al-falah) yang didahului oleh pemanfaatan harta yang memberikan maslahah bagi manusia itu sendiri. Harta dalam aktivitas kehidupan manusia termasuk barang ekonomi yang memiliki nilai. Oleh karenanya, dalam aktivitas ekonomi harta merupakan kebutuhan yang dikonsumsi, diproduks dan didistribusikan. Oleh karenanya, ketiga aktivits tersebut merupakan suatu kesatuan integral untuk mewujudkan maslahah kehidupan. Kegiatan tersebut harus menuju pada tujuan yang sama, yaitu mencapai maslahah yang maksimum bagi umat manusia (P3EI, 2008).

Maslahah terhadap harta dapat diperoleh bila manusia mampu menjaga dan memelihara harta yang dimilikinya. Menurut Jauhar (2009), pemeliharaan atau perlindungan terhadap benda dalam bingkai maqashid syariah terdapat 2 hal yang diperhatikan yaitu (1) memiliki hak untuk dijaga dari para musuhnya, baik dari tindak pencurian, perampasan atau tindakan lain memakan harta orang lain ( baik dilakukan kaum muslimin maupun non muslimin dengan cara yang batil seperti merampok, menipu atau memonopoli; (2) harta tersebut dipergunakan untuk hal-hal yang mubah, tanpa ada unsur mubazir atau menipu untuk hal-hal yang dihalalkan Allah. Harta tidak dinafkahkan untuk kefasikan, minuman keras atau berjudi. Selanjutnya dikatakan bahwa untuk memelihara dan melindungi dan tidak menganiaya harta serta mengambilnya dengan cara yang batil seperi melakukan suap; mencuri; Riba dan penimbunan. Halhal tersebut tidak akan membawa maslahah (manfaat) melainkan mafsadah (kerusakan) 


\section{Elastisitas - Jurnal Ekonomi Pembangunan \\ Vol. 3 No. 2, September 2021}

bagi pemiliki harta tersebut. Semua cara yang disajikan di atas selalu mengacu pada firman Allah yang berada di dala Al-qur'an maupun hadis-hadis Rasulullah saw.

Al-Syatibi sebagaimana yang dikutip oleh Aprianto (2017) telah menguraikan cara menjaga/memelihara harta sesuai dengan ketentuan maqashid syariah, yaitu adanya ketetapan hukum yang dilegalkan oleh Allah tentang diharamkannya mencuri dan sanksi atasnya, diharamkan curang dan berkhianat di dalam bisnis, diharamkannya riba, diharamkannya memakan harta orang lain dengan cara batil, dan diwajibkan mengganti barang yang telah dirusaknya, sehingga dengan demikian terjagalah/terpeliharalah harta. Selain itu peranan maqashif syariah di dalam menjaga/memelihara harta tersebut adalah dengan dilarangnya penimbunan harta dari hal-hal yang dibutuhkan, dilarangnya penumpukan harta di tangan orang-orang kaya, dan diperintahkan untuk berinfak dan sedekah untuk pemerataan harta dalam rangka memberikan kemaslahatan bagi manusia secara keseluruhan.

Perintah untuk menjaga/melihara harta kepada manusia agar harta yang dimiliki harus benar-benar diperhatikan cara memperolehnya. Meskipun secara kuantitatif duniawi harta itu memberikan kepuasaan dan kebahagiaan, namun yang diperolehnya adalah kebahagiaan yang semu tidak ada nilai ukhrawi tidak dapat digapainya. Ia tidak mendapatkan kebahagiaan hakiki karena melupakan akhiratnya. Islam memerintahkan manusia untuk berhati-hati dan menjaga kesucian dan kemurnian harta yang diperolehnya, karena akan menghantarkan dia mampu menggapai al-falah. Manusia sebagai pelaku ekonomi harus mampu menerapkan prinsip ekonomi islam untuk mencapai falah. Menurut Aravik dan Fachry Zamzam, (2020), Ilmu ekonomi islam mencakup tiga aspek dasar yaitu (1) konsumsi, yaitu komoditas apa yang dibutuhkan untuk mewujudkan maslahah; (2) produksi, yaitu bagaimana komoditas yang dibutuhkan itu dihasilkan agar maslahah tercapai; (3) distribusi, yaitu bagaimana sumberdaya dan komoditas didistribusikan di masyarakat agar setiap individu dapat mencapai maslahah.
Harta sebagai sebuah kebutuhan harus dijaga dan dipelihara agar memberikan kemaslahatan. Pemeliharaan terhadap harta tidak dimaksudkan untuk tetap berada didalam genggaman,namun harus dikelola dan disalurkan setelah kebutuhan diri dan keluarga terpenuhi. Harta sebagai kebutuhan pokok harus digunakan pada tempatnya dengan baik serta tidak boros dalam memanfaatkannya. Harta harus dijaga dan dipelihara karena statusnya sebagai titipan dan amanah dari Allah; (2) sebagai perhiasan dalam kehidupan; (3) sebagai ujian dalam menjalani kehidupan; dan (4) sebagai bekal dalam melakukan ibadah (Kemenag RI, 2012).

\section{Pengelolaan Harta}

Harta yang telah dimiliki dan diperoleh manusia dari berbagai ikhtiar yang dilakukan, harus dikelola dan ditata dengan baik. Memelihara harta merupakan kewajiban bagi setiap insan karena sebagai kebutuhan dharuriyah, yang dapat membawa kemaslahatan sehingga akan mengantarkan manusia dapat mencapai kebahagiaan di dunia dan akhirat (falah). Harta atau kekayaan yang dimiliki selain dipelihara harus dikelola secara profesional agar dapat memberikan kemaslahatan diri dan umat pada umumnya. Pengelolaan sebagaimana yang telah diuraikan sebelumnya merupakan sebuah proses yang dilakukan berawal dari perencanaan hingga dimanfaatkan yang memberikan hasil bagi diri maupun orang lain. Demikian halnya dengan harta kekayaan, pengelolaanya tidak hanya yang bergerak namun juga yang tidak bergerak.

Pengeloaan harta yang diamahkan oleh Allah untuk dimiliki haruslah sesuai dengan tatacara dan ketentuan Islam. Rumah tangga Islami harus menyadari bahwa harta merupakan sebuah kebutuhan yang bersifat utama (primer) sehingga harus dikelola dengan baik agar mendapatkan kemaslahatan dan kebahagiaan hakiki. Menurut Masqood (2003), terdapat beberapa prinsip yang dapat dilakukan berkaitan dengan pengelolaan harta atau kekayaan yaitu : (1) Secara penuh memenuhi kebutuhan pokok keluarganya; (2) Barang-barang yang dihasilkan memberikan kenyamanan bagi kehidupan keluarganya; (3) Barang-barang yang didapatkan dianggap sebagai kesukaan Allah SWT atas manusia 


\section{Elastisitas - Jurnal Ekonomi Pembangunan \\ Vol. 3 No. 2, September 2021}

karena barang-barang tersebut memberikan keuntungan dan tidak membahayakan; (4) Menghabiskan sebanyak mungkin hartanya untuk pendidikan anak-anaknya sehingga mereka akan mengembangkan lebih banyak kepada masyarakat dan juga melanjutkan untuk mengumpulkan dengan mengelola kekayaan (harta) dengan cara Islam; (5) Dia bisa memberikan pengeluaran dan tidak membuatnya terlibat dalam hutang yang tidak perlu.

Pengelolaan harta atau kekayaan secara Islami merupakan jalan untuk menuju kebahagiaan sebagaimana yang diinginkan oleh Maqashid Syariah. Penggunaan dan membelanjakan harta dan keuangan yang dimiliki haruslah diawali dengan perencanaan yang matang sehingga dapat terhindar dari hal-hal yang tidak bermanfaat yang menimbulkan ketidaknyamanan dan kerusakan dalam rumah tangga. Kebutuhan rumah tangga baik primer, sekunder maupun tersier selalu meningkat dari waktu ke waktu, sehingga diperlukan sebuah perencanaan apa yang diinginkan dapat diwujudkan dan dipenuhi.

Menurut Tamanni dan Murniati Mukhlisin ( 2013), diperlukan perencanaan dalam mengelola harta (keuangan) dan merupakan bagian penting dalam manajemen rumah tangga (tabbir al-manzil) seorang muslim. Ada beberapa alasan yang dikemukakan perlunya perencanaan, utamanya dalam mengelola keuangan antara lain (1) perencanaan keuangan penting karena hidup butuh perencanaan; (2) perencanaan keuangan penting karena setiap keluarga memiliki impian dan cita-cita masing-masing; (3) perencanaan keuangan merupakan bagian dari maqashid syariah.

Lebih lanjut dijelaskan bahwa harus disusun perencanaan keuangan dengan mengacu pada skala prioritas dharurriyat, hajiyyat dan tahsiniyyat, yaitu :

1. Managing Income (pengelolaan pendapatan) yang merupakan bagian penting dalam perencanaan keuangan;

2. Managing Needs (pengelolaan kebutuhan), dalam konteks maqashid syariah berarti mengatur konsumsi kita terhadap semua keperluan yang bersifat dharuriyyat, dan sebagian kecil hajiyyat dalam menjaga atau memelihara aspek- aspek agama, jiwa, harta, keturunan dan intelek.

3. Managing dreams/want (pengelolaan keinginan). Ekonomi Islam secara tegas memisahkan antara kebutuhan (needs ) dan keinginan (wants). Keinginan atau dreams merupakan hal-hal yang kita inginkan untuk melengkapi kehidupan kita bisa dikarenakan memberi kenyamanan atau memperindah lingkungan sekitar kita.

4. Managing Surplus/Deficit (Pengelolaan Kelebihan/Kekurangan). Untuk mengetahui kondisi ini diperlukan sebuah neraca sehingga dapat diketahui faktor penyebab terjadinya surplus atau defisit.

5. Managing Contingency (Pengelolaan terhadap ketidakpastian). Peristiwa yang terjadi pada masa mendatang tidak dapat diprediksi secara pasti. Contingency muncul karena dalam setiap tindakan dan kegiatan akan ada akibat yang timbul baik yang baik maupun yang buruk. Harus dipersiapkan diri untuk menghadapi resiko yang tidak diinginkan dengan perencanaan dan langkah yang tepat.

Pengelolaan harta kekayaan bagi yang didasarkan pada perencanaan yang baik akan memberikan arah yang jelas tentang penggunaan dan pemanfaatan harta kekayaan tersebut. Jika pengelolaan kekayaan telah berjalan dengan baik, manusia akan semakin termotivasi untuk mencari harta dengan tetap mengacu pada nilai-nilai islami cara memperolehnya. Harta yang baik adalah harta yang diperoleh dengan cara yang halal dan dipergunakan sesuai dengan tempat yang telah ditentukan. Islam secara tegas melarang seseorang mengambil harta yang tidak sesuai dengan ketentuan agama karena akan menghancurkan eksistensi harta itu sendiri. Harta yang dimiliki bersumber dari jalan yang baik dan dilarang pula ditimbun yang dapat merugikan orang lain. Al-Baihaqi mengatakan bahwa harta itu tidak akan tercela dengan sendirinya, maka sesungguhnya harta dunia itu adalah ladang akhirat. Janganlah engkau menimbun pada harta dunia yang beredar pada seseorang. Dan janganlah pula engkau membiarkan terhadap harta dunia, sesungguhnya engkau 


\section{Elastisitas - Jurnal Ekonomi Pembangunan \\ Vol. 3 No. 2, September 2021}

tidak akan memperoleh kebaikan di akhirat kecuali dengannya (Bably, 1999).

Pengelolaan harta kekayaan merupakan jalan untuk terciptanya kedisiplinan diri dalam memelihara sekaligus menjaga harta kekayaan. Mengelola harta dengan baik dan sesuai dengan perencanaan akan menghantarkan seseorang atau rumah tangga dapat menggapai kesejahteraan di dunia maupun di akhirat. Menurut Chairunnisak (2017) , ada empat konsep pengelolaan kekayaan dalam islam, tentunya harus berdasarkan syariay yaitu (1) Bisnis, tabungan di bank, investasi pada properti, dan lain-lain. (2) Peningkatan atau perbaikan kekayaan. Meningkatkan jumlah pengembalian dari capital gain dan pendapatan termasuk melalui penggunaan leverage (utang). (3) Perlindungan kekayaan. Melindungi kekayaan melalui manajemen resiko dan asuransi. (4) Distribusi kekayaan. Mendistribusikan kekayaan melalui zakat dan faraid (warisan).

Harta yang dimiliki oleh manusia yang bersifat sementara ini, supaya dapat memberikan manfaat bagi diri, keluarganya dan orang lain sangat tergantung pada cara memelihara dan mengelolanya. Menurut Faizin dan Nash Akbar (2018), terdapat lima tahapan dalam mengelola harta secara Islami yaitu :

1. Wealth creation/Accumulation atau penciptaan harta, yakni bagaimana seorang muslim memperoleh harta,. Halal hartanya dan halal cara mendapatkannya. Untuk mendapatkan harta, Islam telah memberik arahan bahwa ia harus bersumber dari penghasilan yang halal. Al-Qur'an telah memberi petunjuk kepada manusia bahwa cara untuk memperoleh harta dengan bekerja. Salah satu firman Allah yang berkenaan dengan perintah bekerja adalah dalam surat alJumu'ah ayat 10 yang artinya "Apabila telah ditunaikan shalat, maka bertebaranlah kamu di muka bumi; dan carilah karunia Allah dan ingatlah Allah banyak-banyak supaya kamu beruntung”. sabda : "Usaha mencari rezeki yang halal adalah kewajiban di atas kewajiban" (HR. Abdullah bin Mas'ud).
2. Wealth Consumption atau konsumsi harta, yakni bagaimana seorang muslim mengkonsumsi sebagian dari hartanya. Pembelanjaan utama dari harta yang telah ditetapkan adalah untuk memenuhi kebutuhan diri sendiri sebagaimana firman Allah yang artinya :"...Dan kewajiban ayah memberi makan dan pakaian kepada para ibu dengan cara ma'ruf.....(al-Baqarah, 233).

Rasulullah saw bersabda " Mulailah bersedekah untuk dirimu, jika berlebih maka untuk keluargamu, jika masih berlebih maka untuk kerabat dekatmu, jika masih berlebih maka begini dan begini (HR.Muslim).

3. Wealth purification atau penyucian harta, yakni bagaimana cara menyucikan harta yang telah dimiliki. Sejatinya di dalan harta yang dimiliki oleh setiap manusia terdapat hak orang lain yang meski ditunaikan.

Allah berfirman "...dan orang-orang yang dalam hartanya tersedia bagian tertentu, bagi orang (miskin) yang meminta dan orang yang tidak mempunyai apa-apa (yang tidak mau meminta)..,(Al-Maarij; 24-25).

Rasulullah bersabda : "Sesungguhnya Allah berfirman, Sesungguhnya Kami menurunkan harta untuk mendirikan sholat dan membayar Zakat.

4. Wealth Distribution atau distribusi harta, yakni bagaimana seorang muslim dapat melalukan distribusi hartanya untuk kepentingan dirinya sendiri dan orang lain.

Allah berfirman ....Dan mereka bertanya kepadamu apa yang mereka nafkahkan. Katakanlah: "Yang lebih dari keperluan." Demikianlah Allah menerangkan ayatayat-Nya kepadamu supaya kamu berfikir. (Al-Baqarah, 219).

Rasulullah saw bersabda "Sebaik-baik sedekah adalah lebih dari kebutuhan, dan tangan di atas lebih baik dari tangan di bawah, mulailah dengan yang paling dekat denganmu" (HR. Muslim).

5. Wealth protection atau perlindungan harta, termasuk di dalamnya adalah asuransi dan juga menabung untuk keperluan di masa yang akan datang baik untuk dirinya sendiri atau keluarganya 
yang dapat mandiri secara keuangan. Saving for future event; agar dirinya atas keluarganya tidak meminta-minta.

Allah berfirman "Dan sesungguhnya hari kemudian itu lebih baik bagimu daripada yang sekarang (permulaan) (Ad-dhuhaa; 4).

Rasulullah bersabda : "Seandainya mereka mengetahui dampak tindakan meminta-minta, tentu tidak ada seorangpun yang mau meminta sesuatu kepada orang lain".

Tabungan untuk kepetingan akhirat hendaknya menjadi prioritas dibandingkan dengan tabungan dunia. Meski demikian, hal ini bukan berarti semua harta harus dialokasikan untuk wealth distribution tanpa menyisakan untuk welath protection. Seorang muslim juga harus memiliki sejumlah tabungan dunia untuk mempersiapkan hari esok, termasuk kecukupan keluarga secara keuangan tatkala ditinggalkan.

Harta yang dimiliki oleh setiap insan maupun rumah tangga wajib dipergunakan, dibelanjakan dan dikelola yang bermuara pada diperolehnya manfaat baik bagi diri sendiri, keluarga maupun orang lain. Harta harus dimanfaatkan dan dikelola agar dapat memenuhi berbagai kebutuhan hidup terutama kebutuhan pokok. Penggunaan dan pengelolaan harta semaksimal mungkin agar tidak menimbulkan kerugian bagi orang lain agar tercapai kesejahteraan. Pengelolaan harta yang bermuara pada terapainya kebutuhan hidup baik pokok merupakan implementasi dari perintah untuk menjaga dan memelihara harta yang terdapat dalam maqashid syariah. Pengelolaan harta kekayaan merupakan suatu proses yang harus dilakukan agar kebutuhan terhadap lima unsur utama dapat dijaga dan dipelihara secara berkesinambungan dan merupakan sebuah kewajiban. Harta harus dipergunakan dan dikelola secara tepat sesuai dengan kebutuhan atau berimbang artinya tidak dipergunakan secara boros atau kikir. Harta harus didistribusikan sesuai dengan kebutuhan dan dilarang untuk menimbun karena adanya sifat pelit dan kikir.

Harta harus didistribusikan, tidak boleh ditahan dan ditimbun merupakan salah satu ciri dari ekonomi Islam. Hal ini dimaksudkan harta itu dapat bermanfaat tidak hanya dirasakan oleh pemilik tetapi bermuara pula untuk orang lain. Harta yang ditimbun dan tidak didistribusikan membawa dampak terhadap terciptanya berbagai peristiwa yang membawa kerugian dan kerusakan bagi berbagai pihak. Rasululllah saw pernah bersabda "janganlah di antara kalian saling sakit menyakiti satu dengan lainnya". Harta yang tidak didistribusiskan berdampak pada tidak lancarnya sirkulasi perekonomian. Harta yang ditimbun sangat dibutuhkan oleh orang lain, tidak terjadi proses transaksi, harga tidak stabil yang berpengaruh pada besar kecilnya pendapatan yang diperoleh masyarakat. Jika hal ini terus terjadi maka terjadi kegoncangan ekonomi yang memicu timbulnya krisis ekonomi.

Perintah untuk mengelola harta dengan mendistribusikan harta serta melarang menimbun harta dalam ekonomi Islam merupakan solusi untuk menghindari terjadinyua krisis ekonomi, menghilangkan kecemburuan sosial, menghilangkan terjadi kesenjangan orang yang kaya dan orang miskin, menghilangkan sifat acuh tak acuh terhadap orang,egoistis, sombong dan sikap individualis yang didengungkan oleh sistem ekonomi konvensional. Perintah mendistribusikan harta dan melarang menimbun sekaligus wujud dari adanya perintah untuk menjaga dan memelihara harta dari kerusakan, kemubajiran, tidak memiliki nilai sebagaimana yang termaktub dalam maqashid syariah. Adanya didtribusi harta akan membawa dampak terhadap kehadiran manusia yang bermanfaat bagi manusia lainnya. Rasulullah bersabda "sebaik-baik manusia adalah yang memberikan manfaat bagi manusia lainnya". Jika hal ini dapat dilaksanakan maka manusia akan mampu mencapai kemaslahatan dengan memperoleh kesejahteraan di dunia dan di akhirat (alfalah).

\section{SIMPULAN DAN SARAN}

\section{Simpulan}

Berdasarkan pembahasan di atas dapat ditarik beberapa kesimpulan sebagai berikut :

1. Pemenuhan kebutuhan hidup manusia berupa harta merupakan suatu kewajiban karena termasuk dalam kebutuhan pokok 
atau yang mendesak (dharuriyah). Jika kebutuhan harta tidak dapat dipenuhi, maka kehidupan manusia menjadi tidak stabil dan dapat membawa kepada kerusakan.

2. Harta yang dimiliki oleh manusia wajib hukumnya dijaga dan dipelihara untuk mencapai kemaslahatan dan kebahagiaan hidup di dunia dan akhirat (al-falah). Harta harus dan wajib dijaga serta dipelihara karena akan menentukan harkat dan martabat manusia berkenaan dengan kecenderungan terhadap harta.

3. Pemeliharaan dan menjaga harta sangat ditekankan karena harta memiliki fungsi sosial yaitu sebagai (1) Sirkulatifdistributif; (2) harta selalu berkembang demikian pula nilainya; (3) Efektif.

4. Manusia secara pribadi maupu kelembagaan wajib mengelola harta dengan mengacu pada perencanaan untuk menciptakan kestabilan dalam menggunakan dan membelanjakan harta. Pengelolaan harta harus mengacu pada skala prioritas dharurriyat, hajiyyat dan tahsiniyyat, yaitu : (1) Managing Income (pengelolaan pendapatan); (2) Managing Needs (pengelolaan kebutuhan); (3) Managing dreams/want (pengelolaan keinginan);(4) Managing Surplus/Deficit (Pengelolaan Kelebihan/Kekurangan); (5) Managing Contingency (Pengelolaan terhadap ketidakpastian).

5. Harta harus dikelola dengan mendistribusikannya dan dilarang untuk ditimbun karena berdampak pada stabilitas perekonomian. Penimbunan harta menyebabkan terjadinya peningkatan kebutuhan yang berpengaruh terhadap stabilitas harga dan daya beli.

6. Harta harus dimanfaatkan dan dikelola agar dapat memenuhi berbagai kebutuhan hidup terutama kebutuhan pokok. Penggunaan dan pengelolaan harta semaksimal mungkin agar tidak menimbulkan kerugian bagi orang lain agar tercapai kesejahteraan. Pengelolaan harta yang bermuara pada terapainya kebutuhan hidup baik pokok merupakan implementasi dari perintah untuk menjaga dan memelihara harta yang terdapat dalam maqashid syariah.

\section{Saran-saran}

Berdasarkan simpulan di atas maka manusia harus memperhatikan banyak sedikitnya harta yang menjadi kebutuhan terutama pemenuhan kebutuhan pokok. Manusia harus dapat mengindari prioritas kebutuhan sekunder dengan mengabaikan kebutuhan pokok karena bertentangan maqashid syariah. Pengelolaan harta harus dilakukan dengan mengacu pada rencana yang telah ditetapkan guna menghindari terjadinya berbagai masalah yang muncuk kemudian. Manusia yang memiliki harta yang lebih (kaya) hendaknya mendistribusikan harta dan tidak menimbunnya agar dapat dimanfaatkan oleh orang yang membutuhkannya. Harta diharapkan dapat didistribusikan sesuai kaidah-kaidah islam baik bersifat wajib maupun sunah, karena harta memiliki fungsi sosial dan dapat menghindari terjadinya krisis ekonomi.

\section{REFERENSI}

Al-Faizin, Abdul Wahid dan Nashr Akbar. 2018. Tafsir Ekonomi Kontemporer; Menggali Teori Ekonomi Dari AyatAyat Al-Qur'an. Gema Insani,Jakarta.

Al-Musyaikih, Khalid Bin Ali. 2012. Buku Pintar Muamalah, Akutal dan Mudah diterjemahkan oleh Abu Zidna.Wafa Press; Klaten.

Anwar, Muhammad. 2020. Pengantar Dasar Ilmu Manajemen. Kencana, Jakarta.

Aprianto, Naerul Edwin Kiky, 2017. Journal Of Islamic Economics Lariba. Volume 3. Issue 2. 65-74.

Aravik, Havis dan Fakhry Zamzam, 2020. Filsafat Ekonomi Islam; Ikhtiar Memahami Nilai Esensial Ekonomi Islam. Kencana Prenada Group, Jakarta.

Ash-Shiddieqy, Teungku Muhammad Hasbi. 2009. Penganta Fiqh Muamalah; Membahas Hukum Pokok Dalam Interaksi Sosial Ekonomi. Pustaka Rizki Putra; Semarang.

Ath-Tarsyah, Syaikh Adnan. 2004. Anda dan Harta. Pustaka Al-Kautsar; Jakarta.

Bably, Muhammad Mahmud. 1999. Kedudukan Harta Menurut Pandangan Islam. Kalam Mulia; Jakarta. 
Chalil, ZakuFuad. 2009. Pemerataan Distribusi Kekayaan Dalam Ekonomi Islam. Khazanah Ekonomi Syariah. Erlangga, Jakarta.

Chaudry, Muhammad Sharif. 2012. Sistem Ekonomi Islam ; Prinsip Dasar. Kencana Prenada Group, Jakarta

Choirunnisak. 2017. Konsep Pengelolaan Kekayaan Dalam Islam. Islamic Banking Volume 3 Nomor 1 Edisi Agustus, 2017.

Cholisni, Atiqi dan Kiki Damayanti, 2016. Analisis Maqashid Al-Syari'ah Dalam Keputusan Konsumen Memilih Hunian Islami Pada Perumahan Villa Ilhami Tangerang. Jurnal Isaminomic. Vol. 7 Np.1, April 2016.

Djuwaini, Dimyauddin. 2010. Pengantar Fiqh Muamalah. Pustaka Pelajar; Yogyakarta.

Fakhruddin. 2008. Fiqh dan Manajemen Zakat Di Indonesia. UIN-Malang Press; Malang.

Hadi, Kuncoro. 2012. Implementasi Maqashid Syariah Sebagai Indikator Perusahaan Islami; Jurnal Al-Azhar Indonesia Seri Pranata Sosial, Vol. 1. No.3 Maret 2012.

Handoko, T. Hani. 2013. Manajemen. Edisi 2. BPFE- Yogyakarta.

Jauhar, AhmadAl-Mursi Husain. 2009. Maqashid Syariah. AMZAH, Jakarta.

Jusmaliani, 2011. Pengelolaan Sumber Daya Insani. Bumi Aksara; Jakarta.

Kementrian Agama Republik Indonesia. 2012. Tafsir Al-Qur'an Tematik : Pembangunan Ekonomi Umat. Direktorat Jenderal Bimbingan Masyarakat Islam; Direktorat Urusan Agama Islam dan Pembinaan Syariah; Jakarta.

Masqood, Ruqaiyah Waris. 2003. Harta Dalam Islam. Lintas Pustaka, Jakarta.

Mardani. 2012. Fiqh Ekonomi Syariah; Fiqh Muamalah. Kencana Prenada Group, Jakarta

Musolli, 2018. Maqashid Syariah; Kajian Teorits Dan Aplikatif Pada Isu-Isu Kontemporer. At-Turaas, Volume V, No. 1, Januari - Juni, 2018.

Nasution, Mustafa Edwin, dkk, 2006.Pengenalan Eksklusif Ekonomi
Islam. Kencana Prenada Media Group; Jakarta.

Qadir, Abdurrahman. 1998. Zakat Dalam Dimensi Mahdhah dan Sosial. PT. Radja Grafindo Persada; Jakarta

Rosyidi, Suherman. 2000. Pengantar Teori Ekonomi; Pendekatan Kepada Teori Ekonomi Mikro dan Makro. Edisi Baru. PT. Radja Grafindo Persada; Jakarta.

Salim, Peter dan Yenny Salim, 2002. Kamus Bahasa Indonesia Kontempore (Jakarta: Modern English Press).

Sinn, Ahmad Ibrahim Abu. 2008. Manajemen Syariah; Sebuah Kajian Historis Dan Kontemporer. PT. Radja Grafindo Persada; Jakarta.

Sukirno, Sadono. 2015. Mikroekonomi Teori Pengantar, Edisi Ketiga. PT. RadjaGrafindo Persada; Jakarta.

Susilawati, Nilda, 2015. Stratifikasi AlMaqashid Syariah Dan Penerapannya Dalam Al-Dharuriyat, Al-Hajjiyat, AlTahsiniyyat. Minzani. Vol IX,No.1, Februari 2015.

Tamanni, Luqyan dan Murniati Mukhlisin. 2013. Sakinah Finance, Solusi Mudah Mengatur Keuangan Keluarga Islami. Tinta Media; Solo.

Tim Prima Pena. Tt. Kamus Lengkap Bahasa Indonesia. Gita Media Press.

Yahya, Yusuf, 2020. Kontribusi Pemikiran Imam Syathibi dan Abraham $\mathrm{H}$. Maslow Tentang Kebutuhan Dasar Manusia. Jurnal Al-Mashadiir. Vol. 1 No.2. 2020.

Zaki, Muhammad dan Bayu Tri Cahya, 2015. Aplikasi Maqashi As-Syariah Pada Sistem Keuangan Syariah. Bisnis, Vol. 3. No. 2. Desember 2015. 